\title{
THE EFFECT OF DIFFERENT GROWTH REGIMES ON THE ENDOPHYTIC BACTERIAL COMMUNITIES OF THE FERN, Dicksonia sellowiana HOOK (DICKSONIACEAE)
}

\author{
Irene de Araújo Barros'; Welington Luiz Araújo ${ }^{1 *}$; João Lúcio Azevedo ${ }^{1,2}$ \\ ${ }^{1}$ Laboratório de Biologia Molecular e Ecologia Microbiana, Núcleo Integrado de Biotecnologia, Universidade de Mogi das \\ Cruzes, Mogi das Cruzes, SP, Brasil; '2Departamento de Genética, Escola Superior de Agricultura "Luiz de Queiroz," \\ Universidade de São Paulo, Piracicaba, São Paulo, Brasil.
}

Submitted: February 25, 2010; Returned to authors for corrections: March 17, 2010; Approved: April 26, 2010.

\begin{abstract}
Endophytic bacteria associated with the fern Dicksonia sellowiana were investigated. The bacterial communities from the surface-sterilized pinnae and rachis segments of the plants from the Brazilian Atlantic Rainforest that grew in native field conditions were compared with the bacterial communities from plants grown in greenhouses and plants that were initially grown in greenhouses and then transferred to the forest. From 540 pinnae and 540 rachis segments, 163 (30.2\%) and 346 (64.2\%) were colonized by bacteria, respectively. The main bacterial genera and species that were isolated included Bacillus spp. (B. cereus, B. megaterium, B. pumilus and B. subtilis), Paenibacillus sp., Amphibacillus sp., Gracilibacillus sp., Micrococcus sp. and Stenotrophomonas spp. (S. maltophilia and S. nitroreducens). B. pumilus was the most frequently isolated bacterial species. Amphibacillus and Gracilibacillus were reported as endophytes for the first time. Other commonly found bacterial genera were not observed in D. sellowiana, which may reflect preferences of specific bacterial communities inside this fern or detection limitations due to the isolation procedures. Plants that were grown in greenhouses and plants that were reintroduced into the forest displayed more bacterial genera and species diversity than native field plants, suggesting that reintroduction shifts the bacterial diversity. Endophytic bacteria that displayed antagonistic properties against different microorganisms were detected, but no obvious correlation was found between their frequencies with plant tissues or with plants from different growth regimes. This paper reports the first isolation of endophytic bacteria from a fern.
\end{abstract}

Key words: Brazilian Tropical forest, ferns, 16S rDNA, bacterial diversity, Bacillus

\section{INTRODUCTION}

In the Brazilian Atlantic Rainforest, the slow growing fern, Dicksonia sellowiana, is in danger of extinction because its trunk is widely used as a commercial fertilizer and as a substrate for the cultivation of ornamental plants, such as orchids $(17,38)$. Attempts to produce D. sellowiana plants in greenhouses and then reintroduce them into the Atlantic Rainforest in the state of São Paulo, Brazil, were performed for more than twenty-five years and involved several members of the local community and researchers from the University of Mogi das Cruzes (UMC). In some instances, reintroduction of 
the plants was successful, but in others, the plants did not grow efficiently in greenhouses or were not successfully reintroduced into their natural environments. One possible explanation for this failure could be the imbalance of endophytic microbiota due to the artificial environmental cultivation conditions.

Endophytes are microorganisms, mainly fungi and bacteria, which live inside plant tissues without causing disease symptoms (6, 28). Endophytes are a largely unexplored component of biodiversity, especially in the tropics. Endophytic bacteria possess an ecological niche similar to plant pathogens in that they are sometimes transmitted through seeds (13), which allows them to be used as candidates for biocontrol agents. In order to use endophytes as biocontrol agents, we must first access the microbial richness and try to understand how different environmental conditions are responsible for microbial diversity (2).

Although endophytic fungi have been isolated from fern plants $(11,12,15)$, the presence of bacteria inside of ferns has not yet been studied. Therefore, the aim of this work was to study the endophytic bacterial community in D. sellowiana plants. The diversity between the bacterial microbiota from plants produced under different growth regimes and the importance of bacterial communities for the successful transfer of plants from greenhouses to the field were evaluated. In addition, the production of antimicrobial substances, which may be important for preventing plant diseases in greenhouses and in the field, was studied.

\section{MATERIAL AND METHODS}

\section{Plant material}

Endophytic bacteria were isolated from the rachis and pinnae of healthy D. sellowiana plants produced under three different growth regimes: 1) ten year old greenhouse plants; 2) eight-year-old native field plants; and 3) plants that were initially grown in greenhouses and then reintroduced into the forest about ten years ago. Samplings were collected from the same plants in March and September of 2001 and January of
2004. Three plants were sampled from each growth regime, and 20 rachis and 20 pinnae fragments were collected from each plant during each collection period. A total of 1080 plant segments (540 pinnae and 540 rachis) were analyzed. Plants were located in greenhouses in the Mogi das Cruzes, São Paulo, Brazil and in a fragment of a Brazilian Atlantic Rainforest situated between $23^{\circ} 35^{\prime} 13^{\prime}$ 'S and $46^{\circ} 11^{\prime} 39^{\prime}$ 'W.

\section{Surface disinfection and isolation of endophytic bacteria}

Immediately after collection, rachis and pinnae were washed in running tap water. Surface disinfection was accomplished by performing a stepwise washing procedure: 1) $70 \%$ ethanol for $30 \mathrm{~s}, 2)$ sodium hypochlorite solution $(3 \% \mathrm{v} / \mathrm{v}$ available chlorine) for $3 \mathrm{~min}, 70 \%$ ethanol for $30 \mathrm{~s}$ followed by three rinses in sterile distilled water. To confirm that the plant surfaces were effectively decontaminated, $100 \mu \mathrm{l}$ aliquots of the sterile distilled water that was used in the final rinse were plated onto Tryptic Soy Agar (TSA, Difco: Tryptone 1.5\%, soytone $0.5 \%$, glucose $0.25 \%, \mathrm{NaCl} 0.5 \%$ and agar $1.5 \%, \mathrm{pH}$ 7.3) and bacterial growth was observed daily from three to eight days after incubation at $28^{\circ} \mathrm{C}$. Only rachis and pinnae that were successfully decontaminated were considered for further experiments.

For isolation of bacterial communities, fern pinnae and rachis were cut into $4 \times 4 \mathrm{~mm}$ pieces and placed onto TSA plates containing benomyl $\left(40 \mu \mathrm{g} \cdot \mathrm{ml}^{-1}\right)$, which inhibits fungal growth, and then incubated at $28^{\circ} \mathrm{C}$ for up to 8 days to allow the growth of endophytic bacteria and determine the number of colonized segments. The endophytic incidence (EI), which is expressed as a percentage, was determined for the pinnae and rachis using the same method described by Araujo et al. (5). The EI was calculated using the following formula: EI = $(\mathrm{N} 1 / \mathrm{N} 2) \times 100$, where $\mathrm{N} 1$ is the number of colonized segments, and N2 is the total number of segments that were analyzed. This isolation procedure was used instead of the colony forming unit isolation process (plating a suspension of homogenized segments in saline) because we previously found that bacterial densities were low in the homogenized segments. In addition, the segment plating process allowed the isolation 
of the most common and rapid growing bacteria, which are potentially the most important bacteria for the establishment of plants that were transferred from the greenhouse to the field.

\section{Purification and bacterial identification}

Following the incubation of the TSA plates, all of the bacteria from the plated plant segments were isolated, purified three times by single colony isolation and grouped on the basis of phenotypic characteristics (e.g. colony morphology, colony color, cell shape, motility, spore formation, growth rate and Gram reaction). From these groups, 158 isolates were randomly selected for further characterizations by biochemical analyses (19). Seventy isolates were identified by the fatty acid methyl ester (FAME) technique using whole-cell fatty acids derivatized to methyl esters, which were analyzed by gas chromatography using the MIDI system (Microbial Identification System, Inc., Delaware, USA). Isolates that were not identified by FAME analysis were identified by $16 \mathrm{~S}$ rRNA gene sequencing.

\section{Analysis of endophytic bacteria by 16S rRNA gene sequencing}

Bacterial DNA was extracted according to the method of Araújo et al. (4). A $50 \mu \mathrm{L}$ reaction contained contained $1 \mu \mathrm{l}$ $(0.5-10.0 \mathrm{ng})$ of total DNA, $0.2 \mu \mathrm{M}$ of the P027F primer (5'GAGAGTTTGATCCTGGCTCAG-3'), $0.2 \mu \mathrm{M}$ of the $1378 \mathrm{R}$ primer (5'-CGGTGTGTACAAGGCCCGGGAACG-3'), 200 $\mu \mathrm{M}$ of each dNTP, $3.75 \mathrm{mM} \mathrm{MgCl}_{2}$ and $0.05 \mathrm{U}$ of Taq DNA polymerase (Invitrogen, Brazil) in $20 \mathrm{mM}$ Tris- $\mathrm{HCl}$ (pH 8.4) with $50 \mathrm{mM} \mathrm{KCl}$, was used for amplification of $16 \mathrm{~S}$ rRNA gene. PCR reactions without DNA were included as negative controls in all of the experiments. The reaction conditions were as follows: an initial denaturation of $94^{\circ} \mathrm{C}$ for $4 \mathrm{~min}$; 25 cycles of denaturation, primer annealing and primer extension at $94^{\circ} \mathrm{C}$ for $30 \mathrm{~s}, 63^{\circ} \mathrm{C}$ for $1 \mathrm{~min}$ and $72^{\circ} \mathrm{C}$ for $1 \mathrm{~min}$, respectively; and a final extension at $72^{\circ} \mathrm{C}$ for $7 \mathrm{~min}$. The PCR products were evaluated in a $1.2 \%(\mathrm{w} / \mathrm{v})$ agarose gel stained with ethidium bromide (32).

For bacterial identification, the PCR products were purified using the GFX PCR DNA and gel band purification kit (Amersham Biosciences) and sequenced using the 1378R primer and the Big Dye Terminator System (Applied Biosystems). A comparison of the purified PCR product sequences to the public sequence database (National Center for Biotechnology Information website (http://www.ncbi.nlm.nih. gov) was performed with the basic sequence alignment program BLAST. The determined sequences were aligned, the handling was edited, and the distance matrices (22) and phylogenetic trees (31) were calculated based on neighborjoining algorithms using the MEGA software. The nucleotide sequences obtained in this study have been submitted to GenBank and were assigned the accession numbers of DQ864625-DQ864641 and DQ874622-DQ874625.

\section{Antimicrobial activity}

The antimicrobial activity of the endophytes was evaluated using two rod-shaped Gram-negative bacteria (Escherichia coli and the plant pathogen, Xanthomonas campestris), two Grampositive cocci (Staphylococcus aureus and Micrococcus luteus) and a Gram-positive, rod-shaped bacterium (Bacillus subtilis). All of these bacteria were obtained from the culture collection at the Departamento de Antibióticos, Universidade Federal de Pernambuco, Brazil. Endophytic bacteria were inoculated onto TSA plates and incubated at $28^{\circ} \mathrm{C}$ for two days to allow the diffusion of any possible antimicrobial products (7). After the incubation, chloroform was added to the lid of inverted closed plates, and after approximately $30 \mathrm{~min}$, the lids were opened to allow the evaporation of the chloroform. A thin layer of TSA semi-solid medium $(0.7 \%$ agar $)$ containing each potential antimicrobial-sensitive bacterium was added to the plates. After an incubation period of at least 48 hours at $28^{\circ} \mathrm{C}$, antagonistic activity of the endophytes was determined by measuring the sizes of the inhibition zones around the chloroform-treated colonies.

\section{Statistical analysis}

Analyses of the data were performed with the SAS software package (33). The differences in total isolation 
frequencies among various plants were tested by the Tukey test at $5 \%$ significance.

\section{RESULTS}

\section{Determination of culturable endophytic bacteria in $D$. sellowiana rachis and pinnae}

Endophytic bacteria were isolated from the rachis and pinnae of all of the analyzed plants. In three different sampling periods, the endophytic incidence (EI), ranged from $22.2 \%$ (40 colonized segments from native field plants) to $82.8 \%$ (149 colonized segments from the rachis of the greenhouse plants). From 540 pinnae segments and 540 rachis segments, 163 $(30.2 \%)$ and 346 segments $(64.1 \%)$ were colonized by bacteria, respectively (Table 1). No significant differences were found between the three different collection periods that were performed during different months (data not shown). The number of segments that were colonized varied with the different growth regimes of the plants. Plant segment colonization decreased in the following order: greenhouse $>$ reintroduced $>$ native field plants. In all cases, rachis segments were colonized more frequently by endophytes than pinnae segments (Table 1). This result suggests that the growth of $D$. sellowiana in greenhouses may alter the bacterial endophytic communities, and this effect may persist for several years after the field reintroduction of greenhouse-cultivated plants.

A total of 158 endophytic isolates, which represented distinct groups based on the phenotypic characteristics mentioned in the material and methods, were chosen in proportion to the total number of representatives within each group. These isolates were further characterized with biochemical tests normally used in bacterial classifications (19). From the 158 isolates analyzed, 108 (68.4\%) were Grampositive. Eighty of the 108 Gram-positive bacteria (74.7\%) were rods (Amphibacillus sp., Bacillus spp., Gracilibacillus sp. and Paenibacillus sp.), 22 (19.8\%) were cocci (mainly Micrococcus sp.) and $6(5.5 \%)$ were actinomycetes. From the
50 Gram-negative isolates, $31.6 \%$ belonged to the Stenotrophomonas genus. A total of 70 isolates, which represented the entire community, were selected for further analyses. There were no major qualitative differences between the main groups of endophytic bacterial isolates in the evaluated fern plants (Table 2).

\section{Phylogenetic analysis of endophytic bacteria by 16S rRNA} gene sequence

Partial sequences of $16 \mathrm{~S}$ rRNA gene were aligned, and the phylogenetic relationships among bacterial endophytic isolates were evaluated using a neighbor-joining algorithm (Figs. 1 and 2). Interestingly, B. pumilus separated into two groups: group A2, which is composed of isolates obtained only from reintroduced plants, and group A1, which is composed of isolates from all of the plant categories. In addition, an unidentified Bacillus (isolate EV17) was observed from native plants (Fig. 1).

The endophytic isolates identified as Stenotrophomonas were also evaluated by $16 \mathrm{~S}$ rRNA gene sequencing (Fig. 2). No correlation was observed between bacterial isolates of different growth regimes, plant tissues or sequences. The highest bacterial diversity was observed within the reintroduced and greenhouse plants since 10 and 9 different bacterial species were isolated from these plants, respectively, while only 6 species were isolated from native field plants (Table 2).

\section{Endophytic antimicrobial activity}

The antimicrobial activity of 70 endophytic isolates was evaluated against 5 different bacteria. The results (Table 3) showed that several endophytic isolates inhibited the growth of various bacteria. In some cases, Bacillus endophytes were able to inhibit the growth of a species from the same genus, $B$. subtilis. Similar results were observed for endophytic Micrococcus isolates, which inhibited the growth of M. luteus. These results may be due the production of bacteriocins, which are able to inhibit the growth of other closely related bacteria $(20,29)$ 
Table 1. The number of plant fragments colonized with bacteria and the isolation frequencies (IFs), which are expressed as percentages from the rachis and pinnae and the total isolation frequency (TIF): Dicksonia sellowiana plants grown in different conditions.

\begin{tabular}{lccc}
\hline Plants $^{\S}$ & \multicolumn{4}{c}{ Number of fragment infected (EI \%) } \\
\cline { 2 - 4 } & Rachis & Pinnae & Total \\
\hline $\mathrm{G}$ & $149(82.8) \mathrm{a}$ & $82(45.5) \mathrm{a}$ & $231(64.2)$ \\
$\mathrm{N}$ & $60(33.3) \mathrm{b}$ & $40(22.2) \mathrm{b}$ & $100(27.7)$ \\
$\mathrm{R}$ & $137(76.1) \mathrm{a}$ & $41(22.8) \mathrm{b}$ & $178(49.4)$ \\
Total & $346(64.1)$ & $163(30.2)$ & $509(47.1)$ \\
\hline
\end{tabular}

${ }^{\S} \mathrm{G}$ : greenhouse plants; N: field native plants; R: field reintroduced plants.

${ }^{\dagger}$ Means in column with the same letter are not significantly different at $\mathrm{P}<5 \%$ of Tukey test.

Table 2. The relative population and distribution of the fern endophytic bacterial species in the evaluated Dicksonia sellowiana plants.

\begin{tabular}{lcccc}
\hline Species & \multicolumn{2}{c}{ Host plant } & \multicolumn{2}{c}{ Relative population (\%) } \\
\cline { 2 - 5 } & Reinroduced & Greenhouse & Native & \\
\hline Amphibacillus sp. & 1 & 2 & 1 & 5.7 \\
Bacillus megaterium & 3 & 2 & 0 & 7.2 \\
B. pumilus & 11 & 7 & 5 & 11.4 \\
B. subtilis & 5 & 3 & 0 & 5.7 \\
B. thuringiensis & 3 & 1 & 0 & 1.4 \\
Gracilibacillus sp. & 1 & 0 & 0 & 10.0 \\
Micrococcus sp. & 2 & 3 & 2 & 7.2 \\
Paenibacillus sp. & 2 & 1 & 2 & 11.4 \\
Stenotrophomonas maltophilia & 4 & 3 & 1 & 7.1 \\
S. nitrireducens & 2 & 1 & 2 & $70(100 \%)$ \\
Number of isolates & 34 & 23 & 13 & \\
\hline
\end{tabular}

Table 3. Antimicrobial activity of the endophytic bacteria isolated from Dicksonia sellowiana against various bacterial species.

\begin{tabular}{lcccccc}
\hline Species & Isolates & \multicolumn{5}{c}{ Antagonistic activity against ** } \\
\cline { 2 - 6 } & & Eco & Mlu & Sau & Bsu & Xca \\
\hline Bacillus thuringiensis & $\mathrm{R} 10$ & $++*$ & + & ++ & + & - \\
Bacillus megaterium & $\mathrm{R} 47 ; \mathrm{R} 20$ & - & - & - & - & + \\
Bacillus pumilus & $\mathrm{G} 30$ & + & - & ++ & +++ & + \\
& $\mathrm{F} 17 ; \mathrm{G} 46$ & ++ & + & + & + & - \\
& $\mathrm{R} 1$ & ++ & + & - & + & + \\
& $\mathrm{G} 14 ; \mathrm{F} 4 ; \mathrm{R} 3$ & - & + & - & - & + \\
& $\mathrm{R} 1 / \mathrm{R} 101$ & - & $+/++$ & + & $+/+++$ & + \\
& $\mathrm{F} 8 / \mathrm{R} 12$ & $+++/+$ & $++/+$ & $++/+$ & +++ & + \\
Bacillus subtilis & $\mathrm{R} 23 / \mathrm{G} 11$ & - & - & + & $+/++$ & $-/+$ \\
& $\mathrm{G} 5$ & - & + & - & - & - \\
& $\mathrm{G} 1 ; \mathrm{R} 02$ & + & + & - & + & + \\
Amphibacillus & $\mathrm{R} 11$ & + & + & + & + & - \\
Micrococcus & $\mathrm{G} 11 ; \mathrm{R} 24 ; \mathrm{R} 7$ & - & + & - & - & + \\
Stenotrophomonas & $\mathrm{R} 8$ & + & +++ & - & +++ & - \\
& $\mathrm{G} 17$ & - & - & - & + & - \\
*- no inhibition; & $\mathrm{R} 15$ & - & ++ & - & ++ & +
\end{tabular}

$*_{-}=$no inhibition; += inhibition haloes $0.1-0.5 \mathrm{~cm} ;++=$ inhibition haloes $0.6-1.0 \mathrm{~cm}$;

$+++=$ inhibition haloes $>1.0 \mathrm{~cm}$

$* *$ Eco = Escherichia coli $;$ Mlu = Micrococcus luteus $;$ Sau = Staphylococcus aureus $;$ Bsu = Bacillus subtilis $;$ Xca = Xanthomonas campestris. 


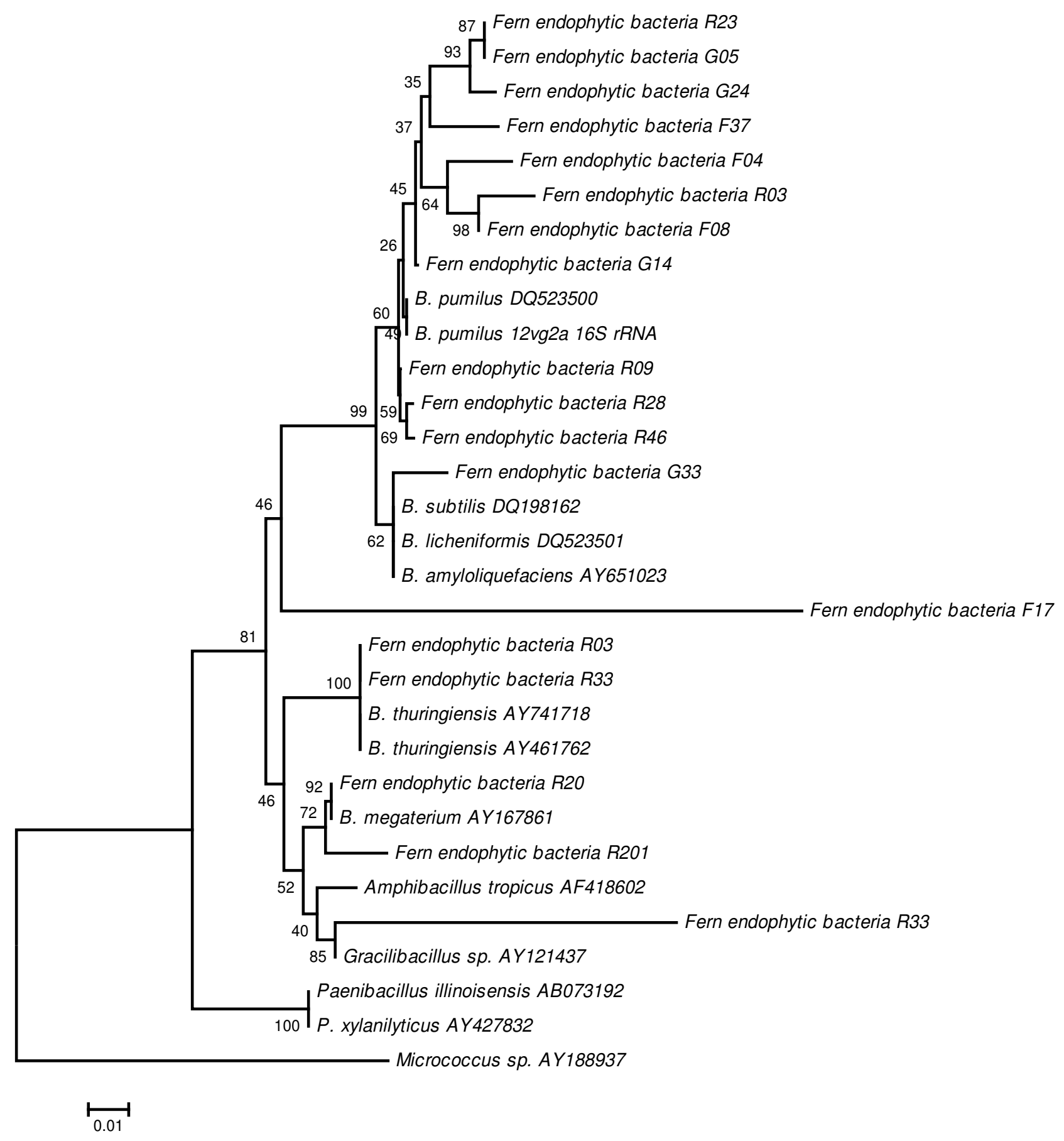

Figure 1. Phylogenetic relationships of Bacillus isolates that are based on partial 16S rRNA gene sequences obtained from the fern endophytic bacteria and closely related sequences that are based on a distance analysis (neighbor-joining algorithm with Jukes-Cantor model; 1,000 bootstrap replicates performed). $\mathrm{R}=$ isolates from reintroduced plants; $\mathrm{F}=$ isolates from native plants; $\mathrm{G}=$ isolates from greenhouse plants. 


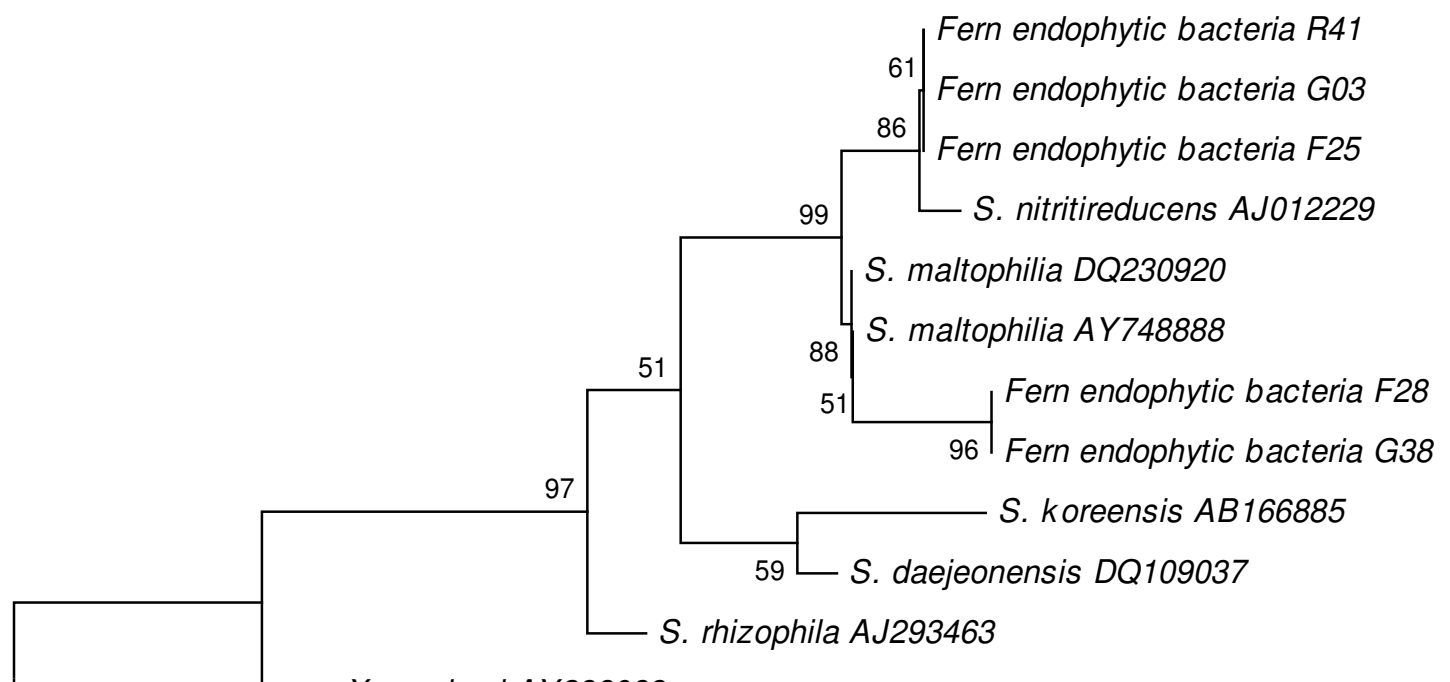

X. gardneri AY288083

K. pneumoniae AF228918

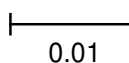

Figure 2. Phylogenetic relationships of Stenotrophomonas isolates that are based on partial 16S rRNA gene sequences obtained from the fern endophytic bacteria and closely related sequences that are based on a distance analysis (neighbor-joining algorithm with Jukes-Cantor model; 1,000 bootstrap replicates performed). $\mathrm{R}=$ isolates from reintroduced plants; $\mathrm{F}=$ isolates from native plants; $\mathrm{G}=$ isolates from greenhouse plants.

\section{DISCUSSION}

In this study, more bacterial endophytes were obtained from isolated D. sellowiana rachis segments than from pinnae segments (Table 1). Because this appears to be the first study regarding the bacterial endophytic communities within ferns, no comparisons to other endophytic communities in $D$. sellowiana or other ferns can be made. The results of this study are not surprising considering the distribution of endophytic bacteria within plants is heterogeneous $(30,1)$, as endophytes are found more frequently in the root and stems than in the leaves $(14,23)$. Our results regarding the incidence of bacterial endophytes in D. sellowiana plants from different growth regimes were especially interesting (Table 2). The endophyte incidence is higher in plants cultivated in greenhouses or in plants that were transferred from greenhouses into the field when compared to native field plants. Plants growing in a nonnative environment, such as a greenhouse, most likely require a higher incidence of endophytes. The endophytic incidence was not affected when greenhouse cultivated plants were reintroduced into the field and continued to remain higher than the incidence found in native field plants. Since D. sellowiana plants reach maturity after 50 to 60 years $(17,38)$, it will be interesting to follow the bacterial endophytic incidence within plants of different ages and during distinct times of reintroduction into the forest to determine if any shifts occur in the bacterial endophytic communities.

Most of the endophytic bacteria isolated from $D$. sellowiana (Table 2) were already reported as endophytes in other plants. Bacillus sp. were the most frequently isolated bacteria and are commonly found in many other plants including cotton (25), corn (14), oak (9), cucumber (24), citrus (5), Eucalyptus spp. seeds (13) and clover (37). Similarly, Micrococcus is an endophyte found in wheat (16) and potato (10) plants. From the Gram-negative endophytic species, Stenotrophomonas maltophilia (Sin.: Pseudomonas 
maltophilia) and S. nitroreducens occurred the most frequently. This genus has also been found in several other plants including the sugar beet (21), citrus (4) and cotton (25) plants. This study defines the first characterization of the endophytic nature of Amphibacillus and Gracilibacillus. Interestingly, we did not find commonly reported endophytic genera, such as Curtobacterium, Pantoea and Methylobacterium (14, 8, 39, 4), in D. sellowiana. This result may reflect the existence of a specific bacterial endophytic community in D. sellowiana, or it may also reflect the limitations of the plant segment isolation method used in this work. The isolation method used in this study potentially favors fast growing bacterial species over slow growing and less competitive bacterial species, which may explain the dominance of Gram-positive bacteria that were isolated.

As shown in Fig. 1, B. pumilus separated into two groups, one of which was formed by isolates derived only from reintroduced plants. In addition, a non-identified Bacillus isolate was found only in native field plants. These results suggest that some bacterial genotypes may be specific for plants from a determined growth regime. This suggestion seems to be the case with three Bacillus species (B. cereus, B. megaterium and B. subtilis) that were found only in greenhouse and field reintroduced plants. B. cereus is known as pathogen of some insects (18), and it may be speculated that this species increases the resistance of the plants to insect pests when a shift occurs in the environment of the plant. The Stenotrophomonas isolates evaluated by 16S rRNA gene (Fig. 2) showed no correlations between different growth regimes and plant tissues. The highest diversity was observed in reintroduced and greenhouse plants, which was demonstrated by the fact that 10 and 9 species were isolated from these plants, respectively, while only 6 species were detected from native field plants. Recent studies have shown that the bacterial diversity may change as a result of different factors including microbial diversity $(4,5)$ and plant genotypes (3).

Similar to the microorganisms within other plants, microorganisms living inside $D$. sellowiana may act as symbionts. Some of the bacteria found inside of D. sellowiana, such as B. cereus, are known to act as biocontrol agents against insects. In addition, some of the endophytic bacteria that were isolated may act as growth promoters that produce phytohormones or fix nitrogen, such as bacteria from the genus Paenibacillus. Bacillus spp. have been shown to have positive effects on the growth of Chrysantemum sp. and also to restrict the development of pathogens (27).

As all D. sellowiana endophytic bacteria were isolated from healthy tissues, the isolates from this study were either non-pathogenic or were maintained inside the plants without causing disease.

In this study, some bacteria that are known to cause human diseases were inhibited by endophytes that were isolated from D. sellowiana. The isolation of endophytic microorganisms from $D$. sellowiana and other plants may be a useful way to explore new products of biotechnological importance $(34,36)$. The only plant pathogen employed in the tests, Xanthomonas campestris, was inhibited by endophytic isolates in some cases, indicating the endophytes may be useful for the control of plant pathogens. Tropical rainforests are remarkable examples of ecosystems where biological diversity can lead to chemical diversity due to constant and active chemical innovation, suggesting that endophytes within these forests and tropical plants could be a source of novel molecular structures and biologically active compounds (35).

The delivery of symbiotic endophytic bacteria into $D$. sellowiana could possibly enhance the growth efficiency of the plant in greenhouses and in the field. Several ways to deliver endophytic bacteria into plants exist. Musson et al. (26) evaluated the effectiveness of these methods by introducing endophytic bacteria into cotton. Some of these methods were highly efficient in delivering bacteria that exhibited biological control against plant pathogens. Endophytic bacteria that were isolated in the present study could possibly be introduced into D. sellowiana in future studies to improve plant growth and survival. The introduction of endophytic bacteria into $D$. sellowiana may augment techniques used to grow the plant in greenhouses and natural environments, facilitating the conservation of this endangered plant species (38). 
The present work described the diversity of the endophytic bacterial community associated with $D$. sellowiana, an endangered fern plant from the Brazilian Atlantic Rainforest, and highlighted the effect of greenhouse growth prior to forest reintroduction on this endophytic community. Based on the results presented in this study, future research is necessary to analyze the role these endophytic bacteria play in plant growth and to evaluate the possibility of increasing the adaptability and fitness of this plant after reintroduction into the forest.

\section{ACKNOWLEDGEMENTS}

This research was supported by Fundação de Amparo à Pesquisa do Estado de São Paulo, Brazil (FAPESP) and Conselho nacional de desenvolvimento científico e Tecnológico $(\mathrm{CNPq})$ for a fellowship to I.A.B. We also thank Dr. Hiroshy Ikuta (University of Mogi das Cruzes) for providing greenhouse plants and information about field plants used in this research and Dr. Itamar Soares de Melo (EMBRAPA, Jaguariuna, São Paulo, Brazil) for identification of Bacillus cereus isolates.

\section{REFERENCES}

1. Andreote, F.D.; Lacava, P.T.; Gai, C.S.; Araújo, W.L.; Maccheroni, Jr. W.; Overbeek, L.S.; van Elsas, J.D.; Azevedo, J.A. (2006). Model plants for studying the interaction between Methylobacterium mesophilicum and Xylella fastidiosa. Can. J. Microbiol. 52: 419-426.

2. Andreote, F.D.; Azevedo, J.A.; Araújo, W.L. (2009). Assessing the diversity of bacterial communities associated with plants. Braz. J. Microbiol. 40: 417-432

3. Andreote, F.D.; Rossetto, P.B.; Mendes, R.; Ávila, L.A.; Labate, C.A.; Pizzirani-Kleiner, A.A.; Azevedo, J.A.; Araújo, W.L. (2009). Bacterial community in the rhizosphere and rhizoplane of wild type and transgenic eucalyptus. World J. Microbiol. Biotechnol. 25:1065-1073.

4. Araujo, W.L.; Marcon, J.; Maccheroni, Jr. W.; van Elsas, J.D.; van Vuurde, J.W.L.; Azevedo J.L. (2002). Diversity of endophytic bacterial populations and their interaction with Xylella fastidiosa in citrus plants. Appl. Environ. Microbiol. 68: 4906-4914.

5. Araujo, W.L.; Maccheroni, Jr. W.; Aguilar-Vildoso, C.L.; Barroso, P.A.V.; Saridakis, H.O.; Azevedo, J.L. (2001). Variability and interactions between endophytic bacteria and fungi isolated from leaf tissues of citrus rootstocks. Can. J. Microbiol. 47: 229-236.
6. Azevedo, J.L.; Araujo, W.L. (2007). Diversity and applications of endophytic fungi isolated from tropical plants. In: Ganguli, B.N.; Desmukh, S.K.; Fungi multifacetad microbes; Anamaya Publishers; New Delhi; Índia. copublished by CRC Press; Boca Raton; USA; pp. 189-207.

7. Azevedo, J.L.; Costa, S.O.P. (1973). Exercícios práticos de genética. Editora Universidade de São Paulo e Cia. Editora Nacional; São Paulo; Brasil

8. Bacon, C.W.; Hinton, D.M. (1997). Isolation and culture of endophytic bacteria and fungi. In: Hurst, C.J.; Knuden, G.R.; McInernay, M.J. et al. Manual of environmental microbiology. ASM Press; Washington; pp.413-421.

9. Brooks, D.S.; Gonzales, C.F.; Appel, D.N.; Filer, T.H. (1994). Evaluation of endophytic bacteria as potential biological control agents for oak wilt. Biological Control 4: 373-381

10. de Boer, S.H.; Copeman, R.J. (1974). Endophytic bacterial flora in Solanum tuberosum and its significance in bacterial ring rot disease. Can. J. Plant. Sc. 54: 115-122.

11. Dreyfuss, M.; Petrini, O. (1984). Further investigations on the occurrence and distribution of endophytic fungi in tropical plants. Bot. Helvetica 94 : 33-40.

12. Duckett, J.G.; Ligrone, R. (1992). A light and electron-microscope study of the fungal endophytes in the sporophyte and gametophyte of Lycopodium cernuum with observations on the gametophyte sporophyte junction. Can. J. Bot. 70: 58-72.

13. Ferreira, A.; Quecine, A.C.; Lacava, P.T.; Oda, S.; Azevedo, J.L.; Araujo, W.L. (2008). Diversity of endophytic bacteria from Eucalyptus species seeds and colonization of seedlings by Pantoea agglomerans. FEMS Microbiol. Lett. 287: 8-14.

14. Fisher, P.J.; Petrini, O.; Scott, H.M.L. (1992). The distribution of some fungal and bacterial endophytes in maize (Zea mays L.). New Phytol. 122: 299-305.

15. Fisher, P.J. (1996). Survival and spread of the endophyte Stagonospora pteridiicola in Pteridium aquilinum; other ferns and some flowering plants. New Phytol. 132: 119- 122.

16. Germida, J.J.; Siciliano, S.D.; de Freitas, J.R.; Seib, A.M. (1998). Diversity of root-associated bacterial associated with field-grown canola (Brassica napus L.) and wheat (Triticum aestivum L.). FEMS Microbiol. Ecol. 26: 43-50.

17. Guedes-Bruni, R.R.; Lima, M.C. (1996). Serrarias do estado do Rio de Janeiro; o conhecimento florístico atual e as implicações para a conservação da biodiversidade na mata atlântica. Eugeniana 22: 9-21

18. Habib, M.E.M.; Andrade, C.F.S. (1998). Bactérias entomopatogênicas. In Alves SB; Controle microbiano de insetos; FEALQ; Piracicaba; pp. 383446.

19. Holt, J.G.; Kreig, N.R.; Sneath, P.H.A.; Staley, J.T.; Williams, S.T. (1994). Bergey's Manual of Determinative Bacteriology. $9^{\text {th }}$ ed. Williams and Wilkins; Baltimore; MD; USA.

20. Jack, R.W.; Tagg, J.R.; Ray, B. (1995). Bacteriocins of gram positive bacteria. Microbiol. Rev. 171: 171-200. 
21. Jacobs, M.J.; Bugbee, W.M.; Gabrielson, D.A. (1985). Enumeration; location and characterization of endophytic bacteria within sugar beet roots. Can. J. Bot. 63: 1262-1265.

22. Jukes, T.H.; Cantor, C.R. (1969). Evolution of protein molecules. In: Munro HN Eds. Mammalian Protein Metabolism. Academic Press; New York; USA; pp. 21-132.

23. Kuklinsky-Sobral, J.; Araújo, W.L.; Mendes, R.; Geraldi, I.O.; PizziraniKleiner, A.A.; Azevedo, J.L. (2004). Isolation and characterization of soybean-associated bacteria and their potential for plant growth promotion. Environ Microbiol 6: 1244-1251.

24. Mahaffe, W.F.; Kloepper, J.W.; van Vuurde, J.W.L., van der Wolf, J.M.; van der Brink, M. (1997). Endophytic colonization of Phaseolus valgaris by Pseudomonas fluorescens strain 89b-27 and Enterobacter asburiae strain JM22. p.180. In: Ryder MH; Stephens PM; Bowen GD. Improving plant productivity in rhizosphere bacteria. CSIRO; Melbourne, Australis.

25. Misaghi, I.J.; Donndelinger, C.R. (1990). Endophytic bacteria in symptom-free cotton plants. Phytopathology 80: 808-811.

26. Musson, J.A.; McInroy, J.A.; Kloepper, J.W. (1995). Development of delivery systems for introducing endophytic bacteria into cotton. Biocontrol Sc. Technol. 5: 407-416

27. Nuth, D.T. (2005). Positive effects of Bacillus spp on the growth of Chrysanthemum spp in vitro and ex vitro. Propagation of Ornamental Plants 5: 146-150

28. Petrini, O. (1991). Fungal endophytes of tree leaves. In: Andrews J; Hirano SS; Spring-Verlag; New York; USA. pp.179-197.

29. Riley, M.A.; Wertz, J.E. (2002). Bacteriocins: evolution; ecology and application. Ann. Rev. Microbiol. 56: 117-137.

30. Ryan, R.P.; Germaine, K.; Franks, A.; Ryan. D.J.; Dowling, D.N. (2008).
Bacterial endophytes: recent developments and applications. FEMS Microbiol. Lett. 278: 1-9.

31. Saitou, N.; Nei, M. (1987). The neighbor-joining method: a new method for reconstructing phylogenetic trees. Mol. Biol. Evol. 4: 406-425.

32. Sambrook, J.; Fritsch, E.F.; Maniatis, T. (1989). Molecular cloning: a laboratory manual. Cold Spring Harbor Laboratory Press; Cold Spring Harbor; NY.

33. SAS Institute (1987). SAS/STAT Guide for Personal Computers Version 6. SAS Institute; Cary; NY; USA.

34. Strobel, G.A. (2002). Rainforest endophytes and bioactive products. Crit. Rev. Biotechnol. 22: 315-333.

35. Strobel, G.; Daisy, B. (2003). Bioprospecting for microbial endophytes and their natural products. Microbiol. Mol. Biol. Rev. 67: 491-502.

36. Strobel, G.A.; Daisy, B.; Castillo, U.; Harper, J. (2004). Natural products from endophytic microorganisms. J. Nat. Prod. 67: 257-268.

37. Sturz, A.V.; Christie, B.R.; Matheson, B.G.; Nowak, J. (1997). Biodiversity of endophytic bacteria which colonize red clover nodules; roots; stems and foliage and their influence on host growth. Biol. Fert. Soil 25: 13-19.

38. Suzuki, C.C.L.F.; Paulilo, M.T.; Randi, A.M. (2005). Substrate and irradiance affect the early growth of the endangered tropical tree fern Dicksonia sellowiana Hook. (Dicksoniaceae). American Fern J. 95: 115125.

39. Zinniel, D.K.; Lambrecht, P.; Harris, N.B.; Feng, Z.; Kuczmarski, D.; Higley, P.; Ishimaru, C.A.; Arunakumari, A.; Barletta, R.G.; Vidaver, A.K. (2002). Isolation and characterization of endophytic colonizing bacteria from agronomic crops and prairie plants. Appl. Environ. Microbiol. 68: 2198-2202. 